Instytut Historii

http://dx.doi.org/10.12775/AHP.2016.006

i Stosunków Międzynarodowych

Uniwersytet Warmińsko-Mazurski

w Olsztynie

KAZIMIERZ GRĄŻAWSKI

\title{
Castrum Zwitinense. Wczesnośredniowieczny zespół osadniczy w Grążawach nad Drwęcą jako ośrodek centralny
}

\section{Castrum Zwitinense. The Early Medieval settlement complex in Grążawy on Drwęca}

Zarys treści. Artykuł prezentuje w sposób syntetyczny wyniki badań archeologicznych przeprowadzonych na obszarze wczesnośredniowiecznego zespołu osadniczego w Grążawach w kontekście jego roli jako gród kasztelański - centrum militarno-osadnicze, administracyjne i religijne.

Słowa kluczowe: miejsca centralne, grody wczesnośredniowieczne, kasztelania.

Miejsca centralne pełniły rozmaite funkcje względem swego otoczenia, ulegały permanentnym przemianom, często dostosowując się do zmieniających się warunków społeczno-politycznych, w jakich przyszło im egzystować. Najczęściej przyjmowały one formy osiedli obronnych - grodów, które bądź to inicjowały powstanie zaplecza osadniczego, bądź stawały się swoistą „sublimacją” wcześniejszego zasiedlenia obszaru. Geneza grodów bynajmniej jednak nie ogranicza się do przesłanek natury gospodarczej. Jak zdają się dowodzić ostatnie studia nad tworzeniem się wczesnośredniowiecznych państw środkowoeuropejskich wpływ na to miały różnorakie uwarunkowania walorów środowiska naturalnego (Dulinicz 1999, s. 97-107), jak i szeroko rozumiany kontekst historyczny, a także uwarunkowania religijne, ideologiczne, społeczne i polityczne (Kurnatowska 1999, s. 53-57; Urbańczyk 1999, s. 61-67). Podłożem kreowania pewnych miejsc na dominujące (centralne) mogła być odpowiednia sieć komunikacyjna (Chudziak 1997, s. 110-111) lub wcześniej rozwinięte zaplecze (Buko 1999, s. 197-203). I chociaż owo zaplecze bywa nieraz dobrze udokumentowane w źródłach pisanych, 
to dopiero wyniki badań archeologicznych, zarówno powierzchniowych, jak wykopaliskowych dają szansę jego pełniejszej oceny (Lewczuk 1999, s. 227-237; Hoczyk-Siwkowa 1999, s. 121-129; Chudziak 1999, s. 137-158). Na podstawie źródeł archeologicznych i paleoekologicznych można obserwować kształtowanie się zaplecza i organizacji przestrzeni na skutek planowanej akcji osiedleńczej państwa piastowskiego. Nie zawsze akcja ta miała wyłącznie podłoże gospodarcze, o czym świadczy zakrojona na szeroką skalę misja chrystianizacyjna skierowana na ziemie pruskie. Ze studiów Waltera Christallera nad ośrodkami centralnymi wynika, że pierwotną kontrolę nad wymianą zastąpiła wyższego rzędu kontrola nad transportem między tymi ośrodkami i centrami decyzyjnymi władzy panującej nad całą strukturą (Moździoch 2002, s. 223). Przejawem tego był późniejszy przymus drogowy, prawo mili, czy miejskie prawo składu. W okresie plemiennym zaś to nie kontrola wymiany dalekosiężnej, ale kontrola ośrodków kultowych zaczęła decydować w walce o dominację polityczną (Urbańczyk 2000, s. 94-95).

Nowsze studia nad rolą miejsc centralnych i ich zaplecza zdają się wskazywać, że rola handlu dalekosiężnego, jako czynnika decydującego o powstaniu i rozwoju centrów była dotychczas przeceniana, co wynikało z relatywnie słabego rozpoznania sieci osadniczej danego obszaru (Moździoch 1999, s. 26). Proces organizacji przestrzeni od ustalania granic zagrody po granice kasztelanii i prowincji wymuszany był w ramach funkcjonującego prawa książęcego. Do wyżej opisywanych centrów należał niewątpliwie zespół osadniczy w Grążawach, stanowiący centrum biskupiej kasztelanii w Świeciu (Zvitinense), położony w widłach Drwęcy i Brynicy.

\section{FUNKCJE GRODU „KASZTELAŃSKIEGO” W ŚWIECIU W ŚWIETLE ŹRÓDEŁ ARCHEOLOGICZNYCH I HISTORYCZNYCH}

Grody kasztelańskie spełniały kilka zasadniczych funkcji wynikających $\mathrm{z}$ ich rangi - administracyjną, gospodarczą, militarną, sądowniczą, mieszkalną i religijną. Wszystkie można odnieść do Świecia, na co wskazują źródła pisane i archeologiczne. Przedstawienie tego ośrodka jako centrum administracyjnego w świetle źródeł pisanych oraz sądy mediewistów w tej sprawie są dość jednoznaczne. Oczywiście należy brać pod uwagę fakt, że najpierw było to książęce centrum zarządzania podległymi włościami, potem zaś występowało w obrębie klucza biskupiej kasztelanii majątkowej, gdzie nastąpił podział uprawnień wynikających z praw przypisańczych i immunitetowych. W pierwszych dziesięcioleciach XII wieku kasztelanie majątkowe tworzono na miejscu zlikwidowanych okręgów grodowych. W końcu XII i XIII wieku kreowano kilka nowych kasztelanii biskupich drogą immunitetu, nie stanowiły one jednak jednostek administracyjnych (Modzelewski 1987, s. 197-198).

Organizacja grodowo-kasztelańska była również podstawowym instrumentem sądowo-policyjnej władzy państwa piastowskiego nad ludnością kraju. 


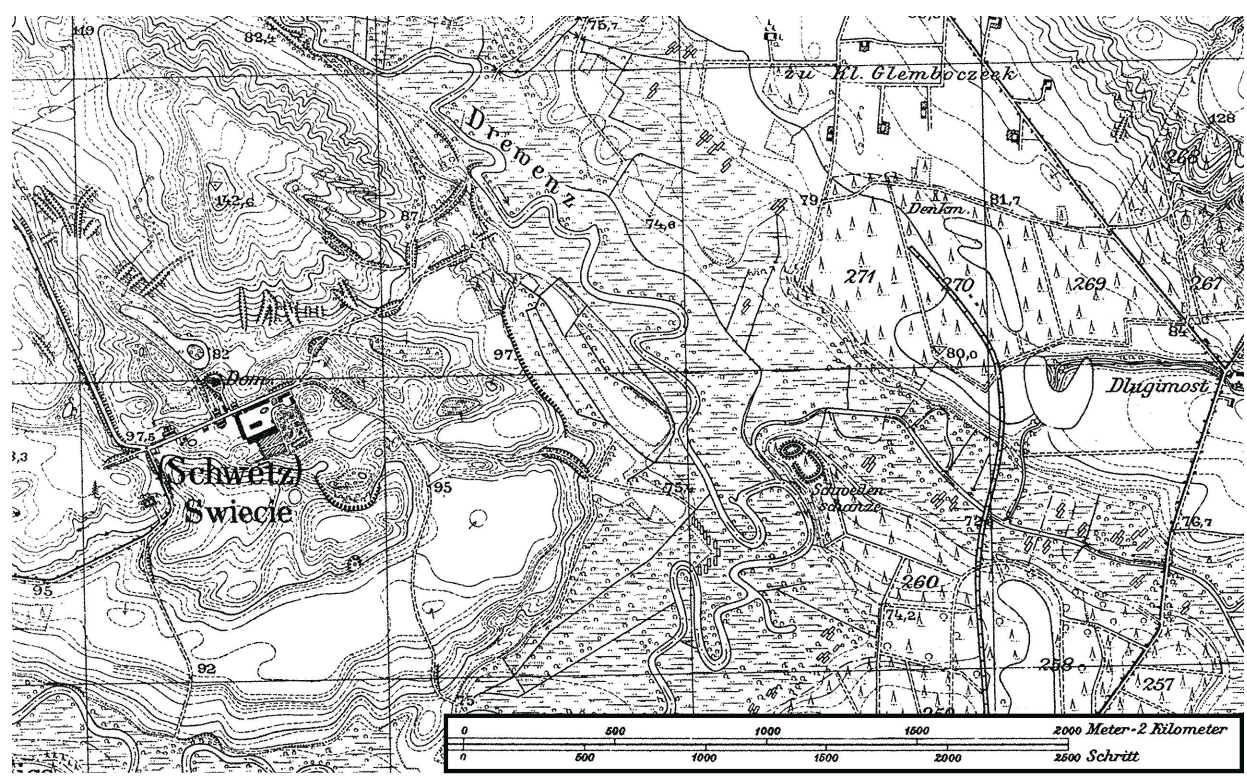

Ryc. 1. Mapa topograficzna z lokalizacją zespołu osadniczego w Grążawach - około 1905 roku (wg Topographische Karte Messtab 1:25000)

Fig. 1. Topographic map presenting location of the settlement complex in Grążawy around 1905 (after Topographische Karte Messtab 1:25000)

Administracja jej była narzędziem, które pozwoliło władzy książęcej objąć kontrolą rozległe obszary państwa i zmonopolizować sądownictwo. Bezpośrednie kierownictwo administracji grodowej spoczywało w rękach trzech zastępców kasztelana: wojskiego, sędziego i włodarza. Właśnie w niektórych kasztelaniach biskupich (np. wolborskiej, łowickiej, sławkowskiej) urzędnik sprawujący z ramienia Kościoła jurysdykcję grodową nad poddanymi biskupa nosił tytuł wojskiego. Biskupstwa nie osadzały tam naczelnego urzędu administracji grodowej, rezerwując zapewne dla siebie całe uposażenie kasztelana; w rezultacie wojski znajdował się na czołowej pozycji (Zbiór ogólny, nr 278). Zdaniem Karola Modzelewskiego zdaje się to przekonywać, że wojski był czymś w rodzaju pierwszego zastępcy kasztelana i pod nieobecność zwierzchnika kierował całą administracją grodową (Modzelewski 1987, s. 132). Podobnie mogło być w przypadku biskupiego grodu w Świeciu nad Drwęcą.

Majątkami ziemskimi księcia zawiadywał włodarz (procurator). Na organizacji grodowej opierał się także pobór danin, nad czym czuwali komornik i podkomorzy. Niekiedy funkcje włodarza i komornika pokrywały się, co poświadcza Księga Elbląska z XIII wieku (NZ, art. 15, p. 25, s. 193).

Z XIII-wiecznych dokumentów wynika, że podworowe należało wszędzie do panującego, zaś stróża do kasztelanów (Modzelewski 1987, s. 143). Oprócz podworowego do dworu książęcego należał stan, a także wielkopolska danina 
wołu (powołowe) i krowy. Natomiast przeznaczenie narzazu nie jest w źródłach jednoznacznie określone. Musiały to być jednak pokaźne dostawy nierogacizny, czego pośrednio dowodzi przykład kościelnej kasztelanii katedry krakowskiej, która w 1251 roku płaciła księciu narzaz w wysokości 14 wieprzy i 6 szynek rocznie (Kodeks dyplomatyczny, nr 32). W kasztelaniach majątkowych, w tym i świeckiej, biskupstwa pobierały na własny użytek te świadczenia, które należały się zwykle urzędnikom grodowym, a z danin przeznaczonych dla księcia płaciły panującemu zryczałtowany dochód. Dotyczyło to ryczałtu za stan, powołoweporadlne-podymne. W początkach XIII wieku biskupstwo płockie pobierało w swoich kasztelaniach majątkowych na własny użytek stróżę i podymne (Zbiór ogólny, nr 301; MPH, NS, s. 433-438; por. też Modzelewski 1980, s. 449-457).

Do obowiązków administracji grodowo-terytorialnej należała ochrona miru targowego i drogowego. $Z$ tego tytułu przysługiwało kasztelanowi uposażenie $\mathrm{w}$ dochodach $\mathrm{z}$ regaliów handlowo-komunikacyjnych. I tak, otrzymywał on połowę dochodów z karczem, targowego i myta na mostach i przeprawach rzecznych w obrębie kasztelanii (Buczek 1964, s. 59-64; Cieśla 1958, s. 184-188).

Kasztelania kościelna (biskupia) różniła się od książęcej zakresem przedmiotowo-terytorialnym, obejmowała bowiem tylko te osady i użytki, które były przedmiotem specjalnych uprawnień biskupa. Na terenie kasztelanii biskupiej obowiązywał rozdział jurysdykcji „,nad ludźmi księcia i rycerzy”. Sądy nad nimi sprawowali kasztelanowie sąsiednich kasztelanii książęcych. Kasztelan kościelny nie mógł przeprowadzić żadnych czynności administracyjnych w stosunku do chłopów książęcych lub rycerskich, a kasztelan książęcy w stosunku do chłopów kapituły katedralnej. Tak więc uprawnienia sądowe i skarbowe biskupstw w swojej kasztelanii nie nosiły charakteru powszechnego władztwa terytorialnego, zaś obejmowały tylko ludność siedzącą we wsiach biskupich (choć wiadomo, że biskup wspólnie użytkował z panującym regalia łowieckie).

Militarną rolę ośrodkowi w Świeciu nad Drwęcą nadawało samo strategiczne obronne położenie na półwyspowatym wyniesieniu w widłach dwu rzek, na peryferiach państwa piastowskiego, przy szlaku handlowym (przeprawa mostowa na Brynicy) oraz imponująca forma rozległych obwałowań obronnych. Z wojskowo-militarnymi funkcjami wiązało się także znaczenie osadniczo-gospodarcze, wynikające z potrzeby utrzymania załogi grodowej oraz zaopatrzenia wojów i ludności służebnej, użytkującej rozległą na ponad 2 ha osadę przygrodową. Zapewne do obowiązków grodzian należało kontrolowanie odległej o około $1 \mathrm{~km}$ przeprawy mostowej na Brynicy. Być może istniała tam komora celna, gdzie pobierano także my to za udostępnienie dogodnego przejścia przez rozległe $\mathrm{w}$ tym miejscu na prawie $200 \mathrm{~m}$ zabagnione rozlewisko tej rzeczki.

Wyniki badań wykopaliskowych prowadzonych w kilku sezonach pozwoliły na rozpoznanie reliktów zabudowy wewnętrznej obu członów grodu, jego umocnień, a także poszczególnych faz użytkowania. Częściowo udało się rozpoznać 


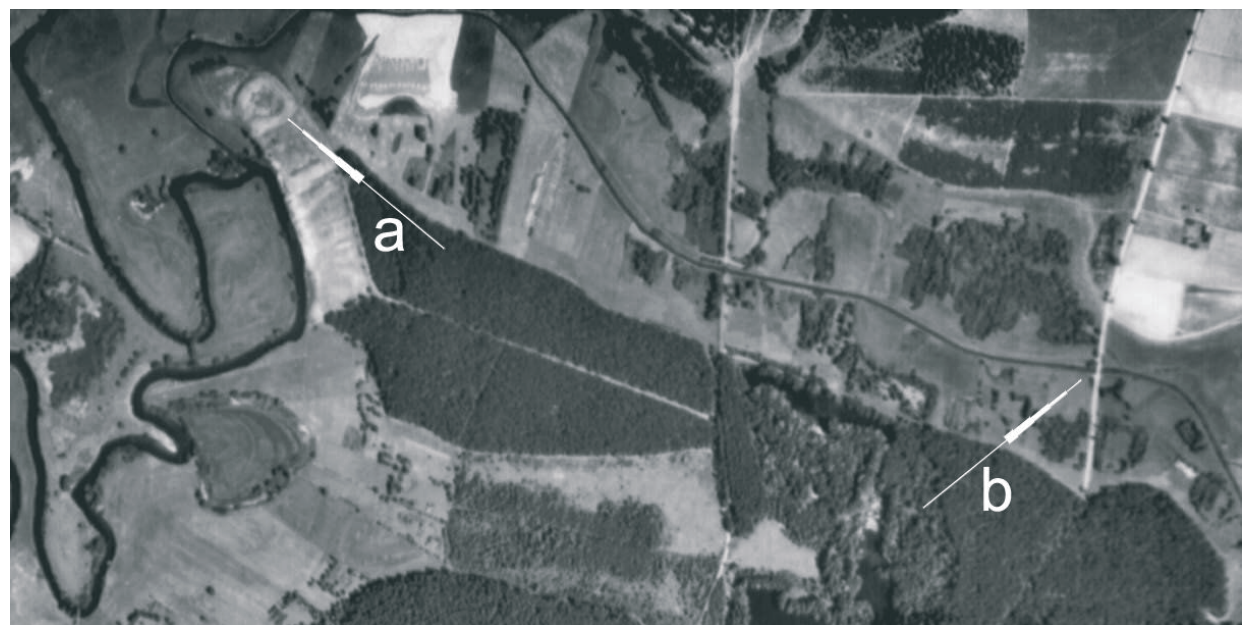

Ryc. 2. Lokalizacja zespołu osadniczego w Grążawach (a) i domniemana przeprawa mostowa (b) (Centralne Archiwum Dokumentacji Geodezyjno-Kartograficznej w Warszawie, fotografia w zbiorach Muzeum w Brodnicy)

Fig. 2. Location of the settlement complex in Grążawy (a) and supposed bridge crossing (b) (Centralne Archiwum Dokumentacji Geodezyjno-Kartograficznej w Warszawie, photo from collection of Museum in Brodnica)

zabudowę i chronologię faz zasiedlenia osady przygrodowej. W zachodniej części, przy wale I owalnego członu grodziska natrafiono na pozostałości sporego zabudowania o wymiarach około 4-5×10 m, które mogło stanowić siedzibę kasztelana(?). W innych miejscach południowej i wschodniej części tego członu odsłonięto nawarstwienia demolacyjno-pożarowe konstrukcji przekładkowej wału, który uległ dwukrotnemu zniszczeniu. Z kolei w II, podkowiastym członie grodziska, w przywałowej (południowej) części odkryto pozostałości trzech faz użytkowania. Nieliczny materiał źródłowy, a także rodzaj nawarstwień wskazywały na refugialny charakter tej części warowni.

Na obszarze osady przygrodowej odsłonięto ponad 70 jam kulturowych, przeważnie owalnego kształtu, z których część stanowiła obiekty mieszkalne, część gospodarcze. Niestety, głęboka orka w czasach współczesnych spowodowała, że nie udało się uchwycić pełnych zarysów domostw, a tylko ich wziemne części. W obrębie osady natrafiono na biegnącą półkolem, w przekroju v-kształtną fosę, dzielącą ją na dwie podobnej wielkości części. Zapewne było to następstwo rozwoju osady otwartej, a fosa pozostała z pierwszej fazy jej użytkowania w XI wieku, być może trwającej do początków XII wieku.

W rozważaniach nad związkami chronologiczno-przestrzennymi materiałów ceramicznych z Grążaw należy dokonać ogólnej charakterystyki lokalnej wytwórczości garncarskiej. W analizowanym zespole z grodziska i osady można określić dominujące cechy techniczno-technologiczne i stylistyczne. Najstarsze 
chronologicznie naczynia ręcznie lepione oraz przykrawędnie i górą obtaczane, gdyby zostały znalezione bez kontekstu stratygraficznego wyznaczałyby horyzont od IX do 1. połowy X wieku. Jednak ich pojedyncze fragmenty występują nawet w zespołach XI- czy XII-wiecznych (np. z Lembarga czy Bobrowa). Niewielki udział egzemplarzy górą obtaczanych w zespołach naczyń całkowicie obtaczanych z ziemi chełmińskiej, datowanych na XI wiek, nie jest zjawiskiem wyjątkowym (Chudziak 1991; Grążawski 2002). W materiałach z grodzisk lubawskich w Zwiniarzu (I faza) czy Nowym Dworze Bratiańskim (I faza) odsetek naczyń częściowo obtaczanych sięga nawet 16-18\%; datowane są one na przełom XI i XII wieku.

Na obszarze dorzecza środkowej Drwęcy oraz na ziemi lubawskiej dla II fazy rozwoju garncarstwa odnotowano przewagę egzemplarzy całkowicie obtaczanych (Grążawski 2002; 2009), reprezentowanych często przez formy esowate i wazowate z wysoko usytuowanym załomem brzuśca, najczęściej zdobione dookolnymi rowkami, często uzupełnianymi linią falistą i nakłuciami grzebykowymi. Z tą fazą łączone są pucharki na pustej nóżce (od 2. połowy XI wieku) (Dąbrowski 1999, s. 227-256; Grążawski 2002, s. 49-50). Warto zwrócić uwagę na kilka takich znalezisk, które uznawane są za wynik pruskiego oddziaływania na ten obszar pogranicza, choć jak słusznie zauważono pucharki te znane są również z kilkudziesięciu miejscowości poza pograniczem, głównie z Mazowsza, Pomorza, Wielkopolski i Śląska, a także z terenu Prus. Przypuszcza się, że stanowiły one element zastawy stołowej elit plemiennych i wczesnofeudalnych (Dąbrowski 1999, s. 251, mapa 1).

Naczynia z opisywanego przedziału chronologicznego charakteryzowały się wysokim standardem wykonania - najczęściej drobnoziarnistym piaskiem zastosowanym do schudzania gliny, średnią grubością ścianek; może to świadczyć o przejściowym charakterze wytwórczości - od mniej zaawansowanej technicznie do wysokostandardowej. Podobne cechy odnotowano w materiałach ceramicznych z Kruszwicy (Dzieduszycki 1982, s. 99). Przyjmuje się, że od 1. połowy XII wieku zaczęła się dominacja naczyń średniościennych, co udokumentowano także na ziemi chełmińskiej (Poliński 1996, s. 212). W tym czasie pojawiły się naczynia z wyodrębnioną i cylindryczną szyjką (Grążawski 2009, s. 46), takie jakie znajdujemy w najbliższych zespołach ze Szczuki czy Osieka Rypińskiego, także z Grążaw, zdobione plastycznymi żeberkami i listwami. Z opisywaną fazą można zsynchronizować okazy z Wieldządza (Boguwolski, Poliński 1997, s. 156), Szynwałdu (Bojarski 1997a, s. 182-183) oraz Klasztorka (Bojarski 1997b, s. 213), odpowiadające schyłkowej III fazie rozwoju garncarstwa na ziemi chełmińskiej oraz fazie IIIB garncarstwa rejonu środkowej Drwęcy, datowanej na 2. połowę XI do 1. połowy XII wieku. Jednak biorąc pod uwagę fakt kilkudziesięciu lat „opóźnienia” rozwoju garncarstwa w rejonie słowiańskiej rubieży osadniczej można je datować na schyłek XI i 1. połowę XII wieku. 


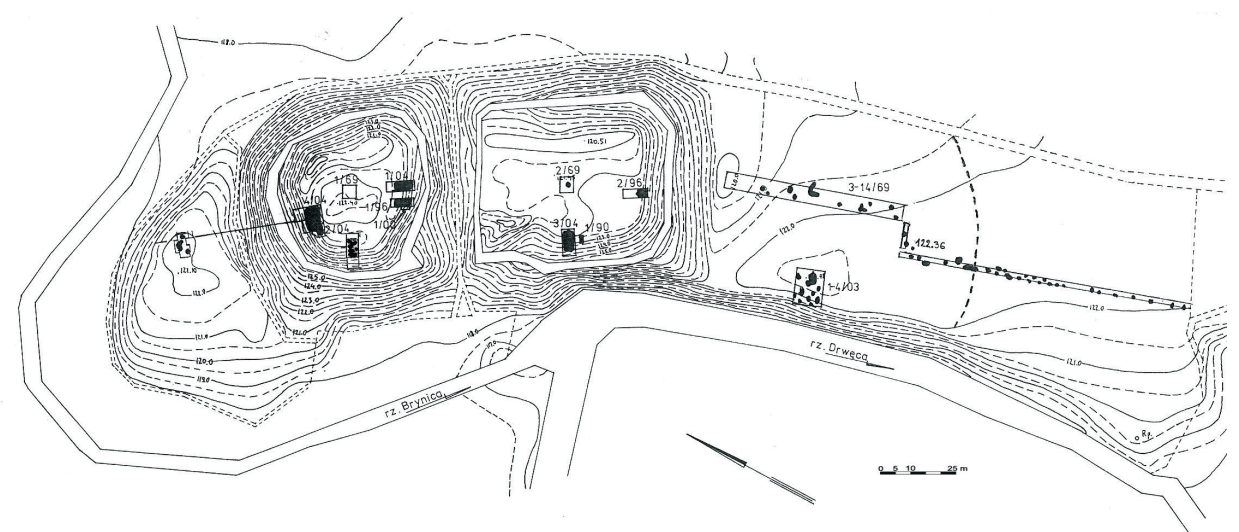

Ryc. 3. Zespół osadniczy w Grążawach. Plan sytuacyjno-wysokościowy z zaznaczonymi wykopami badawczymi oraz obiektami kulturowymi (grodzisko - stanowisko 1; osada przygrodowa - stanowisko 2) (wg Grążawski 2005)

Fig. 3. Settlement complex in Grążawy. Situation-altitude plan with marked research trenches and cultural structures (stronghold site 1; adjacent open settlement - site 2) (after Grążawski 2005)

Kolejna, IV faza rozwoju garncarstwa na obszarze środkowej Drwęcy to okres od 2. połowy XII do 1. połowy XIII wieku, powiązano z nią najliczniejszy materiał ceramiczny pozyskany podczas badań zespołu osadniczego w Grążawach. Znamionują ją zespoły naczyń całkowicie obtaczanych, baniastych, esowatych i dwustożkowatych, ze znacznie wychylonym brzegiem i powszechnie występującym ornamentem rytych, dookolnych rowków i wykonanych grzebykiem nakłuć, a także ornamentem strefowym. Podobnie jak w przypadku poprzedniej fazy odnotowano tu naczynia $\mathrm{z}$ wyodrębnioną szyjką i naczynia z cylindryczną szyjką. Co prawda przeważają okazy średniościenne, ale około $1 / 3$ stanowią cienkościenne, wykonane z gliny schudzonej drobnoziarnistym piaskiem i tłuczniem. W stylistyce naczyń zaobserwowano kultywowanie rodzimych tradycji wytwórczości garncarskiej - występują naczynia szerokootworowe, zdobione ornamentem linii falistej. Analogie do materiałów z Grążaw znajdujemy wśród okazów pochodzących z Brodnicy-Michałowa czy Osieka Rypińskiego (Grążawski 2002, s. 50). Podobieństwa widoczne są też w materiałach z ziemi chełmińskiej, na przykład z Kałdusa (Chudziak 1996, s. 30) oraz Pomorza Gdańskiego - z Ostrowitego (Janowski 2002, s. 215) i Klasztorka (Bojarski 1997b, s. 210-211), czy też z ziemi lubawskiej - z Gutowa i Zwiniarza (Grążawski 2009, s. ryc. 11-15, 17).

Niestety, w materiałach ceramicznych z zespołu osadniczego w Grążawach trudno doszukać się zespołów o stylistyce „pruskiej”, poza dwoma egzemplarzami ręcznie lepionymi, w tym jednym wylewem z charakterystycznym ornamentem paznokciowym (Wróblewski, Nowakiewicz 2003, ryc. 3). 
Podsumowując, trzeba zauważyć, że w periodyzacji rozwoju garncarstwa wczesnośredniowiecznego z ziemi lubawskiej oraz dorzecza środkowej Drwęcy widoczne są pewne przesunięcia czasowe w przenikaniu trendów progresywnych, jakie można zaobserwować na ziemi chełmińskiej czy w Wielkopolsce. Upowszechnianie się naczyń całkowicie obtaczanych miało miejsce dopiero około połowy XI wieku, przy czym dla XII wieku odnotowano jeszcze spory odsetek naczyń częściowo obtaczanych. Około połowy wieku później niż na ziemi chełmińskiej, czyli od początku XIV stulecia, powszechne stały się naczynia siwe (redukcyjne), związane z kolonizacją krzyżacką na tym terenie. Zjawisko to należy uwzględnić w szeroko rozumianej metodzie porównawczej, jako wyznaczniku chronologii stanowisk datowanych na podstawie materiałów ceramicznych. Niezbędne są tu większe serie kalibrowanych analiz radiowęglowych, a najlepiej dendrochronologicznych, weryfikujących tradycyjne datowanie homogenicznych zespołów ceramicznych.

W świetle danych wynikających z periodyzacji naczyń ceramicznych oraz datowań radiowęglowych i dendrochronologicznych, czas funkcjonowania świeckiego zespołu osadniczego przypadał na przełom XI i XII wieku do 1. połowy XIII stulecia, biorąc pod uwagę kilka faz jego użytkowania ${ }^{1}$. Na podstawie dotychczasowych badań możemy przyjąć, że w pierwszej fazie zasiedlenia tego wyniesienia w widłach Drwęcy i Brynicy około połowy XI wieku powstała osada otwarta, niewykluczone, że już w 2. połowie XI wieku lub na przełomie XI i XII stulenia wzniesiono tam dwuczłonową warownię jako jednorazowe założenie urbanistyczne, które było kilkakrotnie niszczone. Pierwsze ślady, przynajmniej częściowego zniszczenia przez pożar umocnień grodu, można datować na połowę XI wieku, późniejsze zapewne na schyłek XII wieku. Wiadomo także, że gród wraz z osadą podgrodową funkcjonował jeszcze w 1. połowie XIII stulecia, jednak trudno przesądzić, czy w późnym średniowieczu był zasiedlony w całości, bo nikłe ślady z tego okresu wykluczają jego intensywne użytkowanie. $\mathrm{Z}$ kolei osada najpierw funkcjonowała w tzw. fazie przedgrodowej, następnie już w kolejnych fazach osadniczych grodu. Cały zespół osadniczy został opuszczony około połowy XIII wieku w wyniku kataklizmu jaki mógł być efektem jednego $\mathrm{z}$ najazdów pruskich plemion (Sasinów) na te tereny. Takie datowanie jest zbieżne

${ }^{1}$ Z I członu grodziska w Grążawach pobrano próby do datowania ${ }^{14} \mathrm{C}$; wykonano je w Laboratorium w Kijowie: $1080 \pm 60 \mathrm{BP}(\mathrm{Ki}-10328) ; 1070 \pm 60 \mathrm{BP}(\mathrm{Ki} 10329) ; 900 \pm 60 \mathrm{BP}(\mathrm{Ki}-10331) \mathrm{z}$ około 60-procentowym prawdopodobieństwem oraz w Poznańskim Laboratorium Radiowęglowym: $940 \pm 45$ (Poz-9516); 1155 \pm 30 (Poz-9514) (obiekt mieszkalny) z 94-procentowym prawdopodobieństwem. Analizy dendrologiczne, przeprowadzone w 1986 roku przez Andrzeja Zielskiego (30 prób) oraz w 2004 roku przez K. Lewandowskiego (15 prób), pozwoliły ustalić, że wspomniane konstrukcje przekładkowe wykonane były wyłącznie z dębu (Quercus sp.). Uzyskano też datowanie ${ }^{14} \mathrm{C}$ (Poznańskie Laboratorium Radiowęglowe) dla dwóch obiektów odkrytych na osadzie przygrodowej: obiektu 7 (ze zwęglonego ziarna zboża) - 1110 \pm 30 BP (Poz-9517) oraz obiektu 15a, (z węgli drzewnych z paleniska) - 1145 \pm 35 (Poz-9518); wszystkie daty z prób pochodzących z osady z około 95-procentowym prawdopodobieństwem. 
z ustaleniami dotyczącymi periodyzacji wytwórczości garncarskiej z Grążaw na tle przemian tego rzemiosła w dorzeczu Drwęcy oraz na ziemi chełmińskiej i ziemi dobrzyńskiej.

Rangę ośrodka w Świeciu nad Drwęcą miał podkreślać pośrednio także fakt planowanej tam fundacji klasztornej in confinio castri Zvitinense, na co zezwalał biskup płocki Gunter niejakiemu Arnoldowi z Opola, jednak czy do owej fundacji w ogóle doszło, trudno jednoznacznie przesądzić (CMas., nr 286). Akcja chrystianizacyjna uległa rychłemu załamaniu w wyniku odwetu ze strony plemion pruskich (opanowanie ziemi lubawskiej w połowie XIII wieku przez Sasinów), co zaowocowało przekazaniem w 1230 roku grodu biskupom płockim, a później translokacji ośrodka dalej na zachód do Michałowa, wzmiankowanego już w 1240 roku (Grążawski 2005). Według klasyfikacji Stanisława Arnolda (1968, s. 241), kasztelanię świecką można uznać za tzw. terytorialną, spełniającą na peryferiach państwa przede wszystkim funkcje militarne, na co pośrednio wskazuje także etymologia nazwy Świecie (świecić niczym latarnia - por. Świecie nad Osą).

Jak wyżej wspomniano Świecie nad Drwęcą, podobnie jak inne grody kasztelańskie, łączyło kilka zasadniczych funkcji - administracyjną, gospodarczą, militarną, sądowniczą, mieszkalną i religijną. Przedstawienie tego ośrodka jako centrum administracyjnego w świetle wyżej wymienionych źródeł pisanych jest dość jednoznaczne. Oczywiście należy brać pod uwagę fakt, że najpierw było to książęce centrum zarządzania podległymi włościami, potem zaś występowało w obrębie klucza biskupiej kasztelanii majątkowej, gdzie nastąpił podział uprawnień wynikających z praw przypisańczych i immunitetowych.

\section{Bibliografia}

Źródła pisane 


\section{Literatura}

Wykaz skrótów
Centrum i zaplecze - Centrum i zaplecze w wczesnośredniowiecznej Europie Środkowej, red. S. Moździoch, Spotkania Bytomskie 3, Wrocław

Arnold S.

$1968 \quad$ Z dziejów średniowiecza. Wybór pism, Warszawa.

Boguwolski R., Poliński D.

1997 Wczesnośredniowieczne osiedle w Wieldzadzu, woj. toruńskie (badania 1995 roku), [w:] Wczesnośredniowieczny szlak ladowy z Kujaw do Prus (XI wiek). Studia i materiały, red. W. Chudziak, Toruń, s. 131-161.

Bojarski J.

1997a Wczesnośredniowieczne grodzisko w Szynwatdzie, woj. toruńskie (badania w 1995 roku), [w:] Wczesnośredniowieczny szlak ladowy z Kujaw do Prus (XI wiek). Studia i materiaty, red. W. Chudziak, Toruń, s. 163-186.

1997b Wczesnośredniowieczny zespół osadniczy w Klasztorku, woj. elblaskie, stanowiska 1 i 4 (badania w 1995 roku), [w:] Wczesnośredniowieczny szlak ladowy z Kujaw do Prus (XI wiek). Studia i materialy, red. W. Chudziak, Toruń, s. 187-217.

Buczek K.

1964 Targi i miasta na prawie polskim, Wrocław.

Buko A.

1999 Wczesnośredniowieczna aglomeracja sandomierska. Początki i podstawy rozwoju, [w:] Centrum i zaplecze, s. 197-2003.

Chudziak W.

1991 Periodyzacja rozwoju wczesnośredniowiecznej ceramiki z dorzecza dolnej Drwęcy (VII-XI/XII w). Podstawy chronologii procesów zasiedlenia, Toruń.

1996 Zasiedlenie strefy chetmińsko-dobrzyńskiej we wczesnym średniowieczu (VII-XI wiek), Toruń.

1997 Dalekosiężne szlaki komunikacyjne w strefie chetmińsko-dobrzyńskiej w X-XI wieku, [w:] Benedyktyńska praca. Studia historyczne ofiarowane O. Pawłowi Sczanieckiemu w 80-rocznicę urodzin, red. O. J. A. Spież, oprac. Z. Wielgosz, Kraków-Tyniec, s. 101-118.

1999 Geneza i rozwój wczesnośredniowiecznych grodów w strefie chetmińsko-dobrzyńskiej, [w:] Studia nad średniowiecznym osadnictwem ziemi chetmińskiej, red. W. Chudziak, Toruń, s. 137-158.

Cieśla I.

1958 Taberna wczesnośredniowieczna na ziemiach polskich, Studia Wczesnośredniowieczne, t. 4, s. 158-222. 
Dąbrowski J.

1999 Wczesnośredniowieczne pucharki ceramiczne z terenu Polski, [w;] Studia nad średniowiecznym osadnictwem ziemi chetmińskiej, red. W. Chudziak, Toruń, s. 227-256.

Dulinicz M.

1999 Uwagi o początkach ośrodków handlowych na poludniowym wybrzė̇u Battyku (VIII-IX w.), [w:] Centrum i zaplecze, s. 97-107.

Dzieduszycki W.

1982 Wczesnomiejska ceramika kruszwicka w okresie od 2. połowy Xw. do połowy $X I V w$. , Wrocław.

Grążawski K.

2002 Przemiany $w$ wytwórczości garncarskiej w rejonie środkowej Drwęcy we wczesnym średniowieczu, Włocławek.

2005 Kasztelania świecka i michałowska. Studia nad kształtowaniem się struktur państwa piastowskiego na pograniczu polsko-pruskim, Włocławek.

2009 Ziemia lubawska na pograniczu słowiańsko-pruskim w VIII-XIII w. Studium nad rozwojem osadnictwa, Olsztyn.

Hoczyk-Siwkowa S.

1999 Małopolska północno-wschodnia w VI-X wieku. Struktury osadnicze, Lublin. Janowski A.

2002 Wczesnośredniowieczna ceramika naczyniowa z Ostrowitego, woj. pomorskie (stanowisko 1), [w:] Studia nad średniowiecznym osadnictwem ziemi chetmińskiej, t. 4, red. W. Chudziak, Toruń, s. 173-232.

Kurnatowska Z.

1999 Centrum i zaplecze. Model Wielkopolski, [w:] Centrum i zaplecze, s. 53-57. Lewczuk J.

1999 Gród i jego zaplecze w świetle badań powierzchniowych AZP na terenie Modzelewski K.

województwa zielonogórskiego, [w:] Centrum i zaplecze, s. 227-236.

1980 Między prawem ksią̇ęcym a władztwem gruntowym. 2: Instytucja kasztelanii majątkowych kościoła w Polsce XII-XIII w., Przegląd Historyczny, t. 71, nr 3, s. 449-480.

1987 Chtopi w monarchii wczesnopiastowskiej, Warszawa.

Moździoch S.

1990 Organizacja gospodarcza państwa wczesnopiastowskiego na Śląsku. Studium archeologiczne, Wrocław.

1999 Miejsca centralne Polski wczesnopiastowskiej-organizacja przestrzeni we wczesnym średniowieczu jako źródło poznania systemu społeczno-gospodarczego, [w:] Centrum i zaplecze we wczesnosredniowiecznej Europie Środkowej, red. S. Moździoch, Spotkania Bytomskie 3, Wrocław, s. 21-44.

2002 Castrum Muntissimum Bytom. Lokalny ośrodek władzy w państwie wczesnopiastowskim, Warszawa. 
Poliński D.

1996 Przemiany w wytwórczości garncarskiej na ziemi chetmińskiej u schytku wczesnego i na początku późnego średniowiecza, Archaeologia Historica Polona, t. 4, Torun.

Urbańczyk P.

1999 Procesy centralizacji wtadzy w okresie przechodzenia do organizacji wczesnopaństwowych, [w:] Centrum i zaplecze, s. 61-67.

2000 Władza i polityka we wczesnym średniowieczu, Wrocław. Wróblewski W., Nowakiewicz T.

2003 Ceramika ,pruska” $i$,stowiańska” we wczesnym średniowieczu, [w:] Stowianie i ich sąsiedzi we wczesnym średniowieczu, red. M. Dulinicz, Warszawa, s. 165-181.

CASTRUM ZWITINENSE. THE EARLY MEDIEVAL SETTLEMENT COMPLEX IN GRĄŻAWY ON DRWĘCA AS A CENTRAL PLACE

Summary

Castellan strongholds met several essential functions resulting from their rank - the administrative, economic, military, judicial, residential and religious ones. All of them, as indicated by written and archaeological sources, refer to Świecie on the Drwęca River. To duties of stronghold-territorial administration belonged marketplace and route peace. This entitled the castellan to salary in trade and communication taxes income. He received half of taverns' incoms, market tax and tolls on bridges and river crossings within the castellany. Military role of the centre in Świecie on Drwęca resulted from both the strategic defensive position itself - on a peninsular elevation at the confluence of two rivers, on the outskirts of the Piast state, at the trade route (bridge crossing on the Brynica River), as well as the vast and impressive form of defensive ramparts. It was also associated with settlement and economic importance, resulting from the need to keep the stronghold crew.

The results of excavations conducted in several seasons allowed to identify remains of inside buildings of both stronghold's segments, its fortifications, as well as different phases of use. In the light of data resulting from the pottery material analysis as well as radiocarbon and dendrochronological dates, the time of functioning of the settlement complex in Świecie on Drwęca is determined to the turn of the $11^{\text {th }}$ and $12^{\text {th }}$ centuries to the first half of the $13^{\text {th }}$ century, taking into account several phases of its use. About the mid-1 $11^{\text {th }}$ century an open settlement was formed, it is possible that in the second half of the $11^{\text {th }}$ century or at the turn of the $11^{\text {th }}$ and $12^{\text {th }}$ centuries was built a two segment fortress as a single urban complex, which was destroyed several times. The first traces of at least partial destruction by fire of the stronghold fortifications date back to the mid$11^{\text {th }}$ century, the later ones probably to the end of the $12^{\text {th }}$ century. We also know that the stronghold along with the adjacent settlement was still in operation in the first half of the $13^{\text {th }}$ century, however, it is hard to determine, if in the late Middle Ages it was settled in full, because faint traces from this period exclude its intensive use. 